\title{
Dual-source computed tomography angiography in patients after bypass grafting - comparison with invasive coronary angiography
}

Dwuźródłowa tomografia komputerowa tętnic wieńcowych u chorych po operacji pomostowania aortalno-wieńcowego - porównanie z inwazyjną koronarografią

\section{Cezary Kępka ${ }^{1}$, Maksymilian P. Opolski², Mariusz Kruk ${ }^{1}$, Jerzy Pręgowski², Ilona Michałowska ${ }^{3}$, Marcin Demkow', Adam Witkowski², Witold Rużyłło ${ }^{1}$}

1 Department of Coronary Artery Disease and Structural Heart Diseases, Institute of Cardiology, Warsaw, Poland

2 Department of Interventional Cardiology and Angiology, Institute of Cardiology, Warsaw, Poland

3 Department of Radiology, Institute of Cardiology, Warsaw, Poland

\section{Abstract}

Post Kardiol Interw 2010; 6, 1 (19): 12-20

Background: Assessment of bypass grafts by invasive coronary angiography (ICA) is bothersome and often requires extra procedure time, contrast load, and radiation exposure.

Aim: To evaluate the ability of dual-source computed tomography angiography (CTA) to detect significant graft disease in symptomatic patients after coronary artery bypass grafting (CABG).

Methods: Thirty (26 men, mean age $66 \pm 9$ years) consecutive post-CABG patients from the prospective ANIN Computed Tomography Angiography Registry who underwent both dual-source CTA and ICA for suspected graft disease were included in the analysis. Coronary artery bypass grafts, anastomotic sites, and distal runoffs with a diameter of $\geq 1.5 \mathrm{~mm}$ were evaluated for the presence of significant stenoses ( $\geq 50 \%$ diameter reduction). Invasive coronary angiography served as a reference standard, and was performed within 30 days of dual-source CTA.

Results: A total of 58 bypass grafts with 56 anastomotic sites, and 54 distal runoffs were evaluable both in dual-source CTA and ICA. Sensitivity, specificity, and positive and negative predictive values of dual-source CTA for the detection of significant lesions in bypass grafts were $100 \%, 92 \%, 86 \%$, and $100 \%$, respectively. In anastomotic sites, dual-source CTA detected significant stenosis with a sensitivity and specificity of $100 \%$ and $96 \%$, respectively. If analysis was restricted to distal runoff segments, sensitivity and specificity were $50 \%$ and $98 \%$, respectively. On a per-patient basis, all patients with at least one significant graft stenosis on ICA were correctly classified using dual-source CTA.

Conclusions: Dual-source CTA permits the reliable assessment of bypass graft disease with high diagnostic accuracy and can be used in clinical routine as a noninvasive test to rule out suspected graft dysfunction in symptomatic post-CABG patients.

Key words: dual-source computed tomography angiography, coronary artery bypass grafts, anastomotic sites, distal runoff segments

\section{Streszczenie}

Wstęp: Ocena pomostów aortalno-wieńcowych w inwazyjnej koronarografii często wiąże się z wydłużeniem czasu badania, podaniem dużej ilości kontrastu oraz większą dawką skuteczną promieniowania.

Cel: Ocena dokładności dwuźródłowej tomografii komputerowej tętnic wieńcowych (CTA) w wykrywaniu istotnych zwężeń w pomostach u chorych z objawami po operacji pomostowania aortalno-wieńcowego (CABG).

Metodyka: Do analizy włączono kolejnych 30 chorych (26 mężczyzn, średni wiek $66 \pm 9$ lat) po CABG z prospektywnego Rejestru Tomografii Komputerowej Tętnic Wieńcowych ANIN, u których wykonano badanie CTA oraz inwazyjną koronarografię. Ocenie poddano pomosty aortalno-wieńcowe, anastomozy oraz dystalne segmenty tętnic natywnych o średnicy $\geq 1,5 \mathrm{~mm}$. Za istotne zwężenie przyjęto zmianę $\geq 50 \%$ redukcji światła naczynia. Wyniki analizy w CTA zostały porównane z inwazyjną koronarografią jako metodą referencyjną. Odstęp czasowy między CTA a koronarografią wynióst $\leq 30$ dni.

Wyniki: Do analizy włączono 58 pomostów, 56 anastomoz oraz 54 segmenty dystalne tętnic natywnych. Czułość, swoistość oraz dodatnia i ujemna wartość predykcyjna dwuźródłowej CTA w wykrywaniu istotnych zwężeń w pomostach wyniosła odpowiednio

\section{Adres do korespondencji/Corresponding author:}

Maksymilian P. Opolski MD, Klinika Kardiologii i Angiologii Interwencyjnej, Instytut Kardiologii, ul. Alpejska 42, 04-628 Warszawa,

tel.: +48 5014443 03; fax: +48 2261338 19; e-mail: maxopol@gmail.com

The study was partially supported by grant MNiSW no: 2957/B/P01/2009/36

Praca wpłynęła 15.03.2010, przyjęta do druku 19.03.2010. 
100\%, 92\%, 86\% i 100\%. Badanie CTA wykrywało istotne zwężenia w anastomozach oraz dystalnych segmentach tętnic natywnych odpowiednio z czułością i swoistością 100\% i 96\% oraz 50\% i 98\%. W analizie pacjentów CTA umożliwiło prawidłowe rozpoznanie u wszystkich chorych z co najmniej jednym zwężeniem w pomoście aortalno-wieńcowym.

Wnioski: Dwuźródłowa CTA z wysoką precyzją wyklucza obecność istotnych zwężeń w pomostach aortalno-wieńcowych $u$ chorych z objawami po CABG.

Słowa kluczowe: dwuźródłowa tomografia komputerowa tętnic wieńcowych, pomosty aortalno-wieńcowe, anastomozy, dystalne segmenty tętnic natywnych

\section{Introduction}

Recurrence of angina is a common problem in the longterm follow-up of patients after coronary artery bypass grafting (CABG) [1]. Although conventional coronary angiography is the reference method for detection of bypass graft disease, it is an invasive and time-consuming procedure that carries potential risk of catheter-related complications [2, 3]. Rapid advances in multislice computed tomography angiography (CTA) have facilitated noninvasive visualization of coronary arteries and bypass grafts with greater diagnostic accuracy [4-8]. Results of studies using 64-slice CTA were promising for the detection of significant stenoses and occlusions in bypass grafts and distal runoffs [9-13]. Recently, a novel dual-source CTA scanner has been introduced that offers the potential for improved temporal resolution [14-16]. However, till now the ability of dualsource CTA to detect bypass graft disease has not been well established. This study evaluated the diagnostic accuracy of dual-source CTA in the comprehensive assessment of symptomatic patients after CABG. Bypass grafts, distal anastomosis sites, and distal runoffs were included in the analysis. Results were compared to invasive coronary angiography (ICA).

\section{Material and methods}

\section{Study population}

The study was designed as a blinded, cross-sectional assessment comparing dual-source CTA with ICA for identification of significant coronary graft disease. Thirty consecutive post-CABG patients ( 26 men, 4 women, mean age 66 years) from the prospective ANIN Computed Tomography Angiography Registry who underwent both dual-source CTA and conventional angiography because of suspected graft disease were included in the analysis. ICA was performed within 30 days of dual-source CTA. Informed written consents for dual-source CTA and ICA were obtained from all patients. Patients with contraindications for administration of contrast media or severe arrhythmia were excluded.

\section{Dual-source CTA protocol}

All scans were performed using dual-source computed tomographic scanner (Somatom Definition, Siemens Healthcare, Forchheim, Germany) during single breathhold. Before CTA scan, medical history, ECG and laboratory tests were recorded in all patients. Intravenous metoprolol (sequential doses of $2.5 \mathrm{mg}$, maximal dose $10 \mathrm{mg}$ ) was administered targeting the stable heart rate $<65$ beats $/ \mathrm{min}$. In addition, sublingual nitroglycerin was given to all patients immediately before CTA scanning. After placement of the region of interest in the ascending aorta, contrast transit time was determined using a biphasic test bolus injection (10 $\mathrm{ml}$ of contrast medium followed by $30 \mathrm{ml}$ of saline solution at a rate of $5-6 \mathrm{ml} / \mathrm{s}$ ). For acquisition of the volume data set, a contrast agent was administered using a triphasic injection (1-contrast medium, 2-contrast + saline mixture, 3-saline) into antecubital vein at a rate of $6 \mathrm{ml} / \mathrm{s}$. The contrast volume ranging from $90 \mathrm{ml}$ to $120 \mathrm{ml}$ was adapted to the scan duration. An ECG-gated retrospective acquisition protocol was used in all patients, with $330 \mathrm{~ms}$ rotation time, $0.6 \mathrm{~mm}$ collimation, and tube voltage of 80 $140 \mathrm{kV}$ adjusted manually for body mass index. Pitch between 0.2 and 0.3 was automatically adapted to heart rate. The temporal resolution was $83 \mathrm{~ms}$ independent of the heart rate. Scan data were reconstructed routinely in mid-to-end diastole (60-70\% of the R-R interval). If motion artifacts were present additional reconstructions were performed in $5 \%$ steps within the full reconstruction window. Images were reconstructed with a slice thickness of $0.6 \mathrm{~mm}$, and reconstruction increment of $0.4 \mathrm{~mm}$, using a soft-tissue kernel (B26f). In the presence of vascular clips or massive calcification additional images were reconstructed with sharp-tissue kernel (B46f) to compensate the blooming artifacts. The scanning range included the entire course of all venous and arterial grafts, including the most proximal part of the internal mammary artery grafts at their subclavian origin.

\section{Dual-source CTA data analysis}

All reconstructed images were evaluated offline using a dedicated workstation (Syngo/Leonardo Workstation, Siemens) with the use of the original transaxial slices, thinslab maximum intensity projections, curved multiplanar reconstructions, and three-dimensional, volume-rendered reconstructions. Dual-source CTA data sets were analyzed by a single experienced observer who was aware of the surgical CABG report but blinded to the patients' clinical data, and results of invasive angiography. All bypass grafts were visually evaluated for the presence of occlusions, and significant stenoses defined as a lumen reduction of $50 \%$ to $99 \%$. Stenoses were classified on the basis of their 
Table 1. Study population characteristics $(n=30)$

Tabela 1. Charakterystyka badanej grupy $(n=30)$

\begin{tabular}{|c|c|}
\hline Age [years] & $66 \pm 9$ \\
\hline Male, n (\%) & $26(87)$ \\
\hline Body mass index $\left[\mathrm{kg} / \mathrm{m}^{2}\right]$ & $28.8 \pm 3.2$ \\
\hline Interval from CABG to dual-source CTA [years] & $7.6 \pm 5.8$ \\
\hline Stable angina pectoris, $\mathrm{n}(\%)$ & $26(87)$ \\
\hline Acute coronary syndrome, $\mathrm{n}(\%)$ & $4(13)$ \\
\hline Diabetes mellitus, n (\%) & $10(33)$ \\
\hline Hypertension*, n (\%) & $24(80)$ \\
\hline Hyperlipidemia ${ }^{\dagger}, \mathrm{n}(\%)$ & $25(83)$ \\
\hline Smoker, n (\%) & $14(47)$ \\
\hline Previous myocardial infarction, n (\%) & $25(83)$ \\
\hline Previous percutaneous coronary intervention, n (\%) & $8(27)$ \\
\hline $\begin{array}{l}\text { Type of evaluable bypass grafts, } n \text { (\%) } \\
\text { left or right internal mammary artery } \\
\text { radial artery } \\
\text { saphenous vein graft }\end{array}$ & $\begin{array}{c}22(38) \\
1(2) \\
35(60)\end{array}$ \\
\hline \multicolumn{2}{|c|}{$\begin{array}{l}{ }^{*} \text { Defined as blood pressure } \geq 140 / 90 \mathrm{~mm} \mathrm{Hg} \text { and/or use of antihy- } \\
\text { pertensive medication }\end{array}$} \\
\hline \multicolumn{2}{|c|}{$\begin{array}{l}\dagger \text { Defined as total serum cholesterol level } \geq 200 \mathrm{mg} / \mathrm{dl} \text { and/or use of } \\
\text { a lipid-lowering agent }\end{array}$} \\
\hline \multicolumn{2}{|c|}{$\begin{array}{l}\text { CABG - coronary artery bypass grafting, CTA - computed tomogra- } \\
\text { phy angiography }\end{array}$} \\
\hline \multicolumn{2}{|c|}{$\begin{array}{l}\text { *Zdefiniowane jako ciśnienie krwi } \geq 140 / 90 \mathrm{~mm} \mathrm{Hg} \text { i/lub stosowanie } \\
\text { leków hipotensyjnych }\end{array}$} \\
\hline \multicolumn{2}{|c|}{$\begin{array}{l}\text { †Zdefiniowane jako catkowite stężenie cholesterolu } \geq 200 \mathrm{mg} / \mathrm{dl} \text { i/lub } \\
\text { stosowanie leków obniżających stężenie cholesterolu }\end{array}$} \\
\hline $\begin{array}{l}\text { CABG - pomostowanie aortalno-wieńcowe, CTA - tom } \\
\text { puterowa tętnic wieńcowych }\end{array}$ & afia kom- \\
\hline
\end{tabular}

location in the body of the graft or at the anastomotic site. In addition, all evaluable anastomotic sites and distal runoffs (native coronary arteries distal to graft implantation) were assessed for the presence of significant stenosis. Only grafts and distal runoff segments with diameter $\geq 1.5 \mathrm{~mm}$ were analyzed.

\section{Invasive angiography}

Invasive coronary angiography, including selective catheterization of the grafts or graft stumps, was performed by experienced cardiologists via a femoral approach. Images were obtained using a standard angiography system (Axiom Artis, Siemens, Germany). All standard orthogonal views for native coronary arteries and at least two orthogonal views for each bypass graft were obtained. Angiograms were evaluated by a single experienced observer who was blinded to the dual-source CTA findings. All images were interpreted for graft patency, graft stenosis, anastomotic stenosis, and distal runoffs stenosis. Narrowing of at least $50 \%$, by visual assessment of the lumen diameter (both in native distal runoffs or graft conduits) was considered significant.

\section{Statistical analysis}

Results were described as counts in percent or as mean \pm SD. The main analysis was performed on a per-graft basis, evaluating the presence of significant stenosis or occlusion in a given bypass graft, and expressed as sensitivity, specificity, positive predictive value, and negative predictive value with their respective $95 \%$ confidence interval $(\mathrm{Cl})$. Calculations were performed separately for the bypass grafts, for the anastomotic sites, and for the distal runoff vessels using the VassarStats website for statistical computation (http://faculty.vassar.edu/lowry/VassarStats.ht $\mathrm{ml}$ ). Additionally, in the per-patient analysis, subjects were classified as positive for graft disease if there was a significant stenosis in any bypass graft.

\section{Results}

During the period from February 2009 through December 2009, a total of 30 patients with 58 bypass grafts (23 arterial grafts and 35 venous grafts), 56 anastomotic sites, and 54 distal runoffs were evaluated both in CTA and ICA. Patient characteristics are listed in table 1.

According to ICA, 39 (67\%) of evaluable bypass grafts were patent and non-stenotic (fig. 1.), while the remaining 19 (33\%) presented with either complete occlusion (6 grafts, 10\%) or significant stenosis (13 grafts, 23\%). All 6 occlusions (100\%) and 13 graft stenoses (100\%) were correctly recognized using dual-source CTA. Ten of the stenoses were located in the body of the bypass grafts (fig. 2.), while 3 stenoses were found at the distal anastomotic sites. Of the patent and non-stenotic grafts, 36 of 39 (92\%) were correctly detected in CTA, whereas in 3 cases false-positive findings were observed. All of the 3 false-positive lesions were located in venous grafts, of which 2 were placed at the distal anastomotic sites to the first diagonal branch, and the second obtuse marginal branch. The remaining false-positive lesion was identified at the proximal third of the venous graft to the intermediate branch. Thus, for the detection of significant graft disease (stenosis or occlusion) in dual-source CTA, a sensitivity of $100 \%$ (95\% Cl 79-100), specificity of $92 \%$ (95\% Cl 78-98), negative predictive value of 100\% (95\% Cl 88-100), and positive predictive value of $86 \%(95 \% \mathrm{Cl} 64-96)$ were found. Dual-source CTA findings are listed in table 2.

Based on ICA findings, there were 52 patent grafts supplying 54 evaluable distal coronary runoffs by 56 anastomotic sites. Of the evaluable anastomotic sites, 53 (95\%) were patent and non-stenotic (fig. 3.), while the remaining $3(5 \%)$ presented with significant stenosis (fig. 4.). All 3 anastomotic stenoses (100\%) and 51 of 53 (96\%) patent and non-stenotic anastomotic sites were correctly identified in dual-source CTA. In 2 cases, the presence of a significant lesion was incorrectly suspected on the basis of CTA, of which both were placed at the venous anastomotic sites to the first diagonal branch, and the second obtuse marginal branch, respectively. Thus, for 

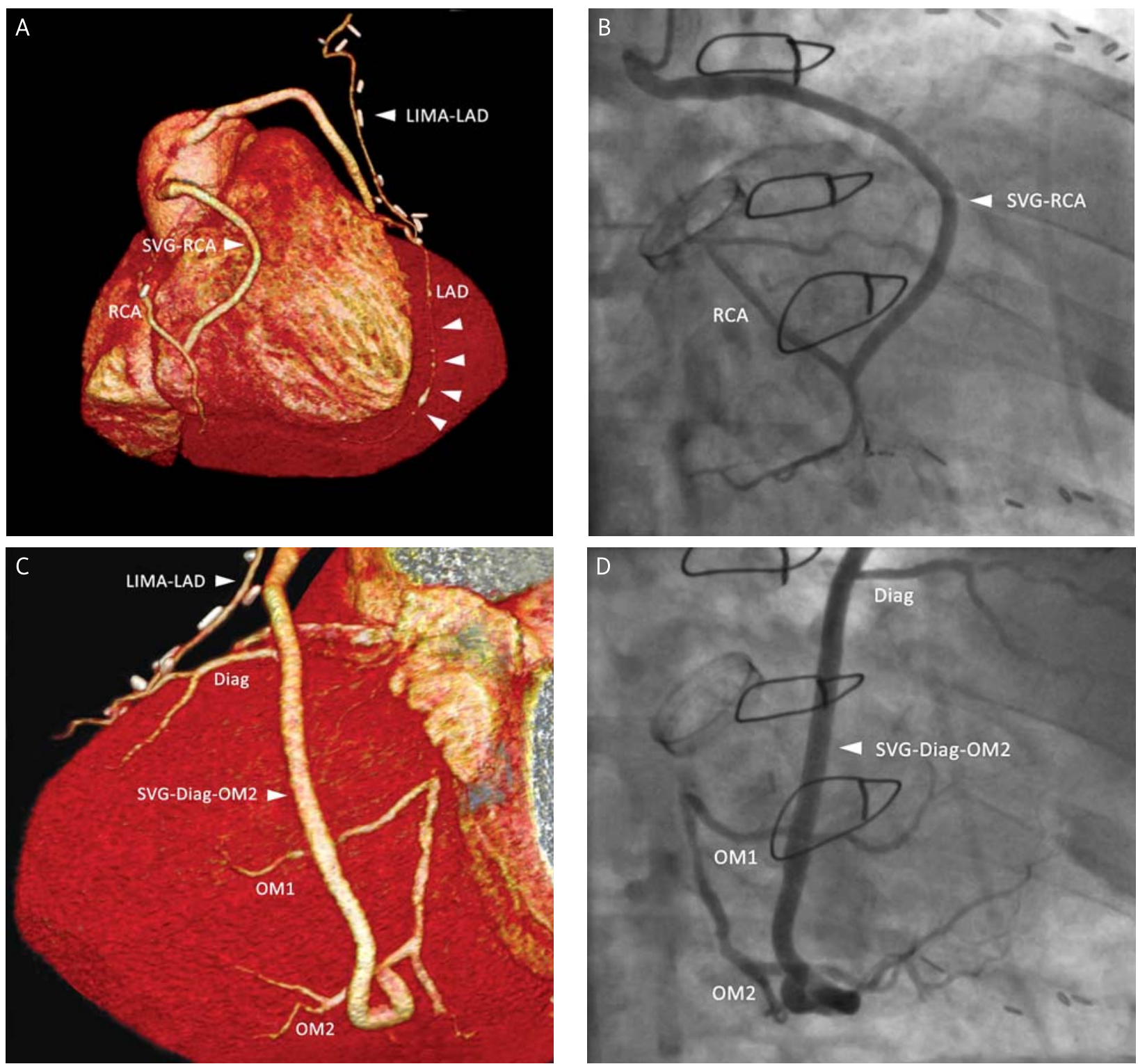

Fig. 1. A - three-dimensional volume rendered reconstruction demonstrates patent left internal mammary artery graft to the left anterior descending coronary artery, and patent vein graft to the right coronary artery. Arrowheads indicate significant lesions in the distal run-off segment of the left anterior descending coronary artery. B - corresponding invasive angiography of the patent and non-stenotic venous graft to the right coronary artery. $\mathrm{C}$ - three-dimensional volume rendered reconstruction demonstrates patent and non-stenotic venous jump graft to the first diagonal branch and second obtuse marginal branch. D - corresponding invasive angiography confirms normal venous jump graft

Diag - diagonal branch, LAD - left anterior descending artery, LIMA - left internal mammary artery, OM - obtuse marginal branch, RCA - right coronary artery, SVG - saphenous vein graft

Ryc. 1. A - drożny pomost tętniczy z lewej tętnicy piersiowej wewnętrznej do gałęzi przedniej zstępujacej oraz drożny pomost żylny do prawej tętnicy wieńcowej w trójwymiarowej rekonstrukcji objętościowej. Strzałki wskazuja istotne zwężenia w dystalnym segmencie gatęzi przedniej zstępującej. B - korespondujący obraz angiograficzny prawidłowego pomostu żylnego do prawej tętnicy wieńcowej. C - trójwymiarowa rekonstrukcja objętościowa prawidłowego żylnego pomostu skaczącego do pierwszej gatęzi diagonalnej i drugiej gałęzi marginalnej. $D$ - angiografia potwierdza obraz prawidłowego pomostu skaczącego

Diag - gałąż diagonalna, LAD - gałąź przednia zstępująca, LIMA - lewa tętnica piersiowa wewnętrzna, OM - gałąź marginalna, RCA - prawa tętnica wieńcowa, SVG - pomost żylny 

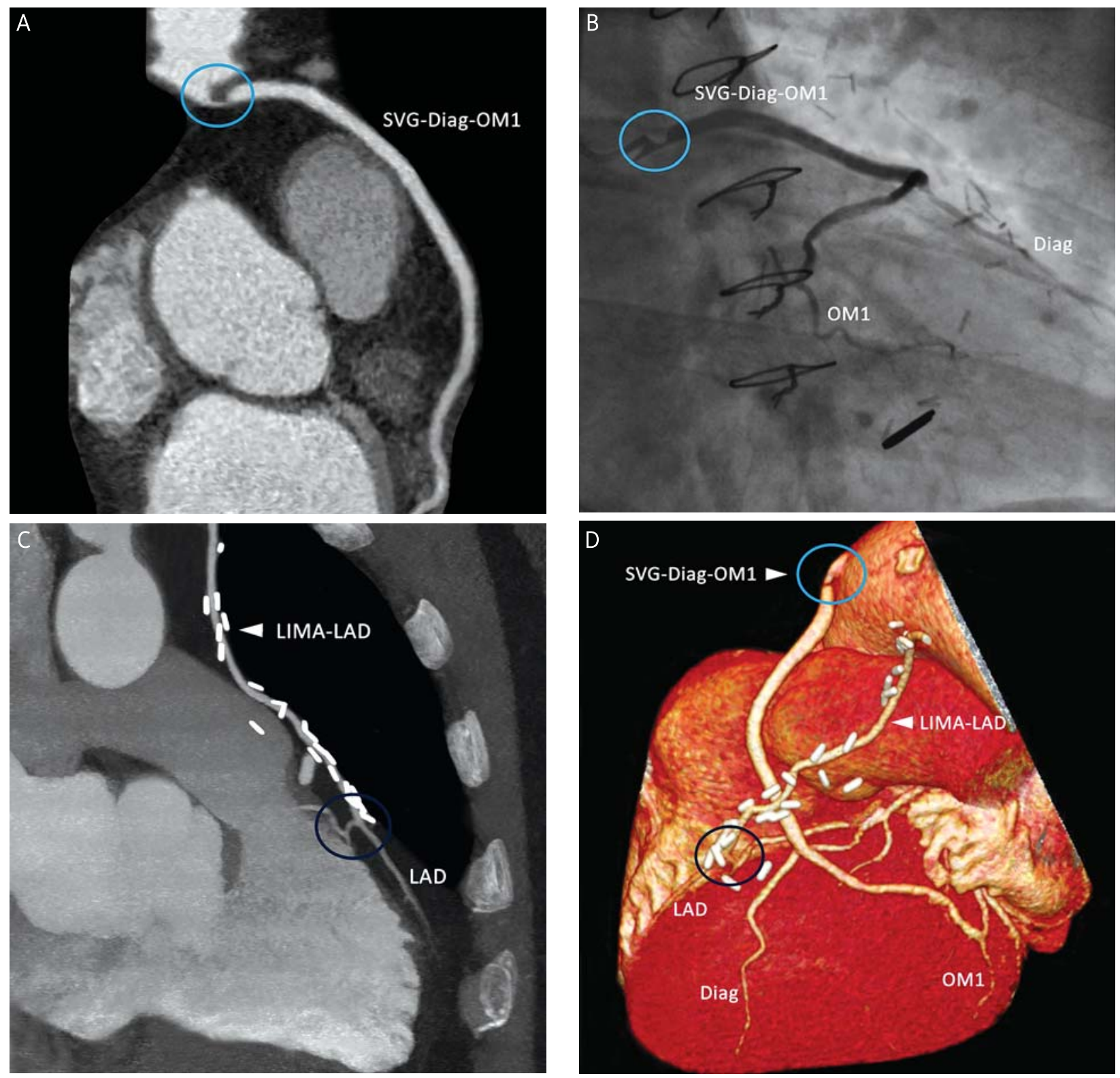

Fig. 2. A - curved multiplanar reconstruction demonstrates critical stenosis in the proximal part of the venous jump graft to the diagonal branch and the first obtuse marginal branch (pale blue circle). B - corresponding invasive angiography confirms critical stenosis in the proximal segment of the venous jump graft. $\mathbf{C}-$ sagittal maximum-intensity projection visualizes the distal section and anastomosis of the patent and non-stenotic left internal mammary artery graft to the left anterior descending coronary artery (navy blue circle). D - three-dimensional volume rendered visualization of critical stenosis in the proximal part of the venous jump graft and normal anastomotic site to the left anterior descending coronary artery. Numerous metal clips along the arterial graft course are visible

Diag - diagonal branch, LAD - left anterior descending artery, LIMA - left internal mammary artery, OM - obtuse marginal branch, SVG - saphenous vein graft

Ryc. 2. A - krytyczne zwężenie w początkowym odcinku żylnego pomostu skaczącego do gatęzi diagonalnej i pierwszej gatęzi marginalnej w rekonstrukcji wielopłaszczyznowej po krzywej (błękitny okrąg). B - korespondujacy obraz angiograficzny potwierdza krytyczne zwężenie w początkowym odcinku żylnego pomostu skaczacego (błękitny okrag). C - prawidłowy obraz dystalnego odcinka i anastomozy (granatowy okrąg) pomostu tętniczego z lewej tętnicy piersiowej wewnętrznej do gatęzi przedniej zstępującej w strzatkowej rekonstrukcji maksymalnej intensywności. D - krytyczne zwężenie w żylnym pomoście skaczącym (błękitny okrąg) i prawidłowa anastomoza pomostu tętniczego z gatęzią przednią zstępującą (granatowy okrąg) w trójwymiarowej rekonstrukcji objętościowej. Widoczne klipsy naczyniowe wzdłuż przebiegu pomostu tętniczego

Diag - gatąź diagonalna, LAD - gatąź przednia zstępująca, LIMA - lewa tętnica piersiowa wewnętrzna, OM - gatąź marginalna, SVG - pomost żylny 
Table 2. Diagnostic accuracy of dual-sorce CTA for the detection of significant graft and distal runoff disease Tabela 2. Dokładność dwuźródłowej CTA w wykrywaniu istotnych zwężeń w pomostach i dystalnych segmentach tętnic natywnych

\begin{tabular}{lcccccccccc} 
& $\mathrm{n}$ & TP & TN & FP & FN & Sensitivity [\%] & Specificity [\%] & PPV [\%] & NPV [\%] & Accuracy [\%] \\
\hline All bypass grafts & 58 & 19 & 36 & 3 & 0 & $100(79-100)$ & $92(78-98)$ & $86(64-96)$ & $100(88-100)$ & 95 \\
\hline Anastomotic site & 56 & 3 & 51 & 2 & 0 & $100(31-100)$ & $96(86-99)$ & $60(17-93)$ & $100(91-100)$ & 96 \\
\hline Distal runoffs & 54 & 2 & 49 & 1 & 2 & $50(9-91)$ & $98(88-100)$ & $67(13 \%-98)$ & $96(85-99)$ & 94
\end{tabular}

CTA - computed tomography, TP - true positive, TN - true negative, FP - false positive, FN - false negative, PPV - positive predictive value, NPV - negative predictive value, between brackets: $95 \% \mathrm{Cl}$

CTA - tomografia komputerowa tętnic wiencowych, TP-prawdziwie dodatnie, TN-prawdziwie ujemne, FP-fatszywie dodatnie, FN-fałszywie ujemne, PPV - dodatnia wartość predykcyjna, NPV - ujemna wartość predykcyjna, w nawiasach: $95 \% \mathrm{CI}$
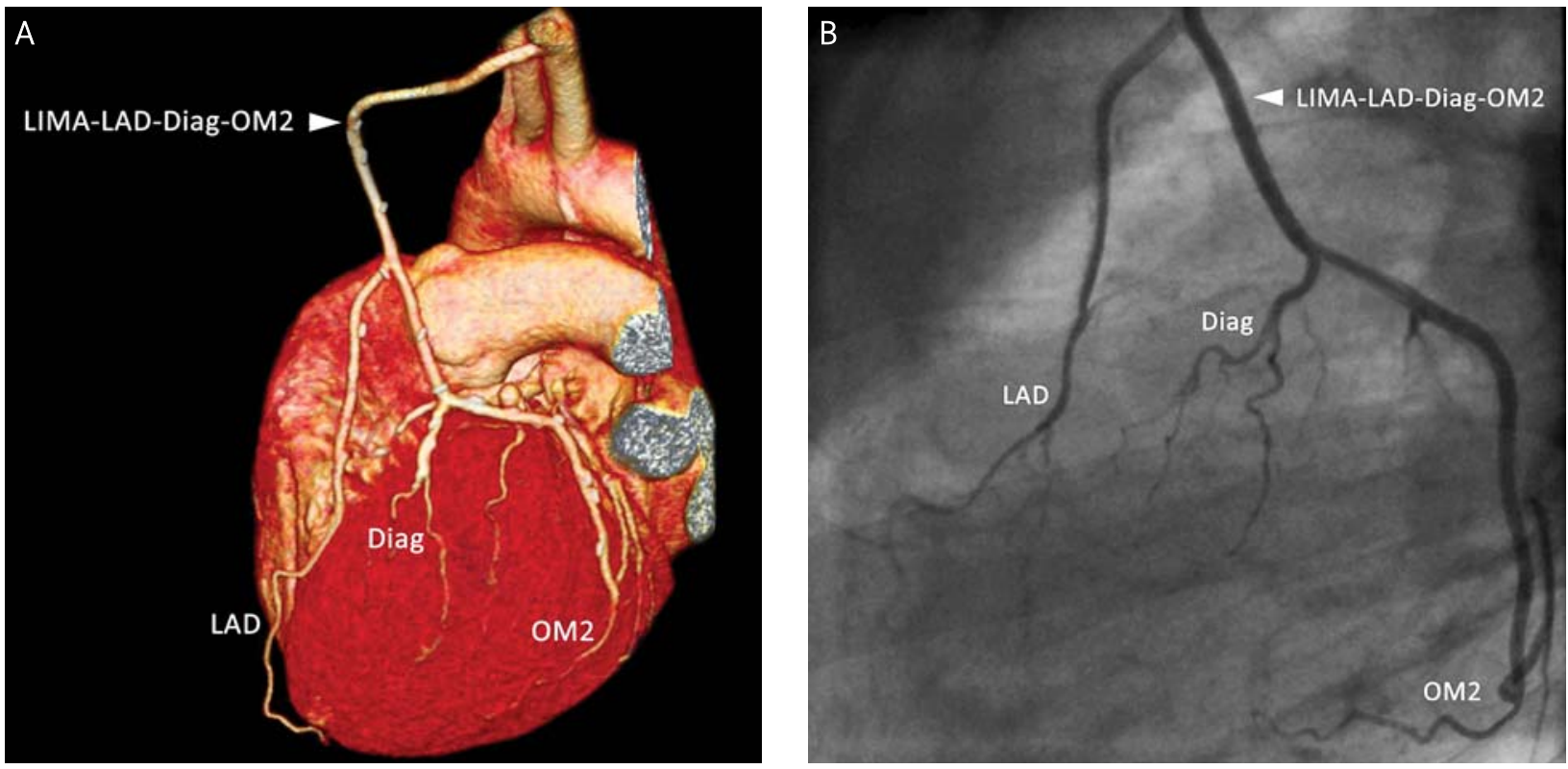

Fig. 3. A - three-dimensional volume rendered reconstruction demonstrates patent and non-stenotic arterial jump graft to the left anterior descending coronary artery, first diagonal branch and second obtuse marginal branch. B - corresponding invasive angiography confirms dual-source CTA findings. Note patent and non-stenotic anastomotic sites

Diag - diagonal branch, LAD - left anterior descending artery, LIMA - left internal mammary artery, OM - obtuse marginal branch

Ryc. 3. A - trójwymiarowa rekonstrukcja objętościowa skaczącego pomostu tętniczego do gatęzi przedniej zstępującej, pierwszej gatęzi diagonalnej i drugiej gatęzi marginalnej. B - angiografia potwierdza obraz prawidłowego pomostu skaczącego. Widoczne trzy prawidłowe anastomozy pomostu

Diag - gałąz diagonalna, LAD - gatąź przednia zstępująca, LIMA - lewa tętnica piersiowa wewnętrzna, OM - gałą́ marginalna

the detection of significant lesion at the anastomotic site in dual-source CTA, a sensitivity of $100 \%$ (95\% Cl 31-100), specificity of $96 \%$ (95\% Cl 86-99), negative predictive value of $100 \%$ (95\% Cl 91 to 100$)$, and positive predictive value of $60 \%(95 \% \mathrm{Cl} 17-93)$ were found.

Of the 54 evaluable distal coronary runoffs, 50 (93\%) were patent and non-stenotic, while the remaining 4 (7\%) presented with significant lesions. In 2 of 4 (50\%) significant stenoses, the presence of distal runoff disease was confirmed by CTA (fig. 1.). The 2 false-negative runoff lesions were located in the first and second obtuse marginal branches supplied by the radial artery and venous graft, respectively. In 49 of 50 (98\%) patent and non- stenotic distal runoffs, stenoses were correctly ruled out using dual-source CTA, whereas in 1 case a false-positive finding was observed. The false-positive lesion was located in the distal runoff segment of the right coronary artery. Thus, for the detection of significant distal runoff disease in dual-source CTA, a sensitivity of $50 \%(95 \% \mathrm{Cl} 9-91)$, specificity of $98 \%$ (95\% Cl 88-100), negative predictive value of $96 \%$ (95\% Cl $85-99)$, and positive predictive value of $67 \%$ (95\% Cl 13-98) were found.

In the per-patient analysis, 2 patients were excluded owing to a limited evaluability of the CTA scan in 1 patient (motion artifacts), and inability to selectively cannulate a bypass graft in ICA. All 21 (100\%) patients with 

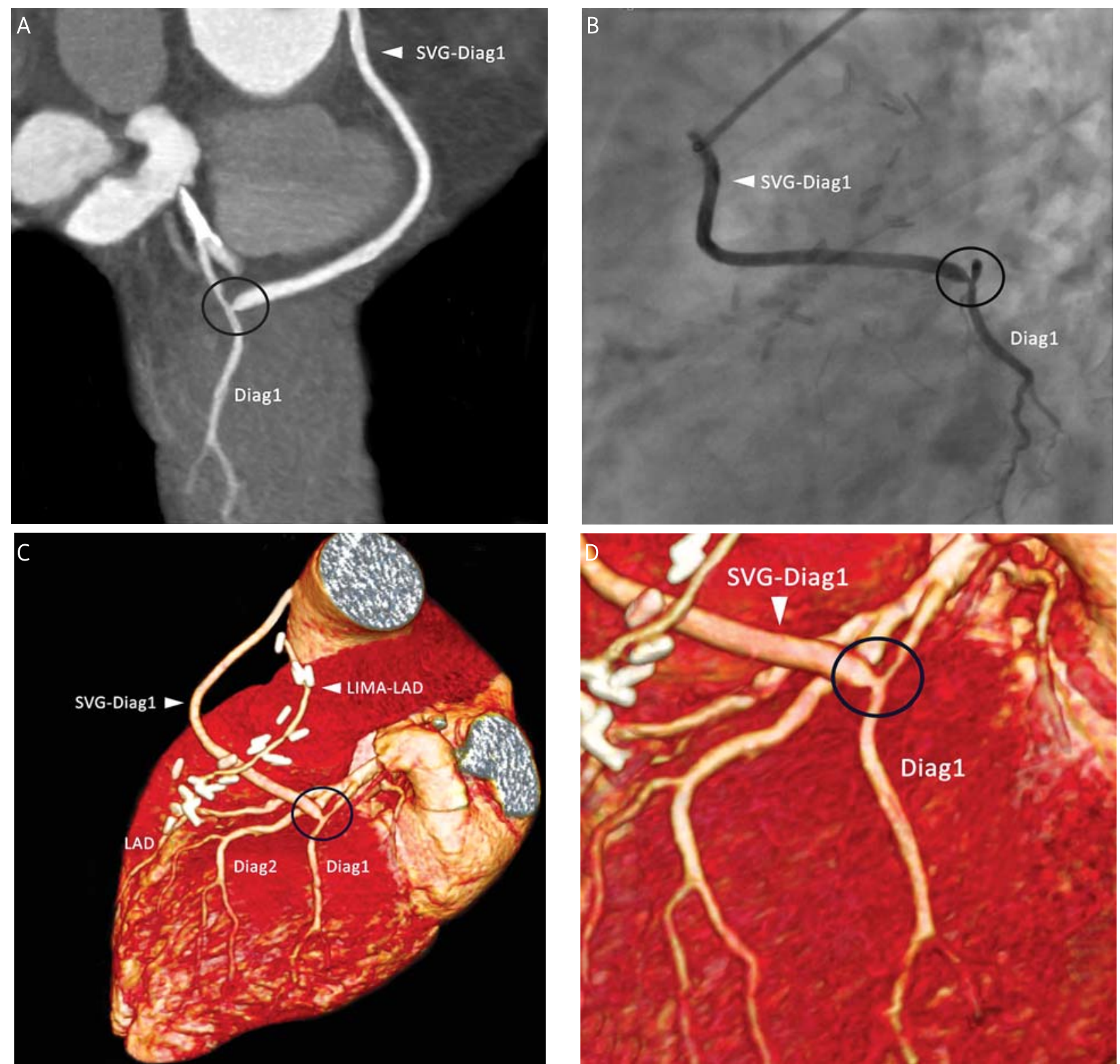

Fig. 4. A - curved multiplanar reconstruction reveals stenosis at the anastomotic site of the venous graft to the first diagonal branch (navy blue circle). B - corresponding invasive angiography confirms tight stenosis at the anastomosis of the venous graft. $\mathbf{C}$ - three-dimensional volume rendered visualization of the stenotic lesion at the anastomotic site to the first diagonal branch. Numerous metal clips along the left internal mammary graft are visible. $\mathbf{D}$ - magnified three-dimensional view of the stenotic anastomosis

Diag - diagonal branch, LAD - left anterior descending artery, LIMA - left internal mammary artery, SVG - saphenous vein graft

Ryc. 4. A - wizualizacja istotnego zwężenia w anastomozie żylnego pomostu do pierwszej gałęzi diagonalnej (granatowy okrag) w rekonstrukcji wielopłaszczyznowej po krzywej. B - korespondujący obraz angiograficzny potwierdza obecność istotnego zwężenia w miejscu wszycia pomostu. C - trójwymiarowa rekonstrukcja objętościowa zwężenia w miejscu anastomozy do pierwszej gatęzi diagonalnej. Widoczne klipsy naczyniowe wzdłuż przebiegu tętniczego pomostu z lewej tętnicy piersiowej wewnętrznej. D - trójwymiarowa rekonstrukcja objętościowa zwężonej anastomozy w powiększeniu

Diag - gałąż diagonalna, LAD - gatąź przednia zstępująca, LIMA - lewa tętnica piersiowa wewnętrzna, SVG - pomost żylny

$\geq 1$ significant graft stenosis on ICA were correctly classified using dual-source CTA. Of the remaining 7 patients with an angiographically normal grafts, the presence of significant stenosis was correctly ruled out in 4 (57\%) patients, whereas 3 patients were incorrectly classified as having significant graft disease. 


\section{Discussion}

The present study is the second to assess the diagnostic accuracy of dual-source CTA in the evaluation of significant coronary graft disease in symptomatic patients after CABG. Our findings showed high diagnostic accuracy for the detection of either complete graft occlusion or significant graft stenosis using dual-source CTA and are consistent with previous studies using 64-slice CTA [9-13].

Multislice CTA systems with 16 or more detectors have resolved some of the practical limitations of CTA imaging in patients after CABG. Studies using 16-slice CTA technology reported sensitivities between $80 \%$ and $96 \%$ with specificities between $85 \%$ and $95 \%$ for the detection of significant graft disease [6-8]. Preliminary results with the latest generation 64-slice CTA by Pache et al., yielded a sensitivity of $98 \%$ and specificity of $89 \%$ for identification of obstructive graft disease [9]. Similarly, the assessment of stenosis or occlusion of bypass grafts by 64-slice CTA in a large prospective study resulted in a sensitivity of $97 \%$ with specificity of $97 \%$ [10]. Recently, Nazeri et al. confirmed high diagnostic accuracy of 64-slice CTA for noninvasive assessment of bypass grafts in symptomatic patients after CABG [13]. The introduction of dual-source CTA scanner with $2 \mathrm{x}$-ray tubes and detectors offers an alternative approach to improve temporal resolution for cardiac imaging [13-15]. In the present study, the dualsource CTA demonstrated a sensitivity of $100 \%$ and specificity of $92 \%$ for the detection of significant graft disease, and compares favorably with the reported diagnostic accuracy of 64-slice CTA.

The only report evaluating dual-source CTA for the assessment of significant graft disease in 52 symptomatic post-CABG patients, yielded a diagnostic accuracy of $100 \%$ [17]. This is consistent with the presented specificity and negative predictive value of $100 \%$, whereas the occurrence of 3 false-positive findings resulted in lower sensitivity and positive predictive value in our study. This might be explained by a fixed patients enrollment based on the prior investigation by both dual-source CTA and ICA in our study. In addition, with a high prevalence of significant graft disease and high body mass index in our population, a possibility of significant image quality impairment should be taken into account. Finally, the overestimation of significant coronary lesions was more apparent in distal graft segments with a relatively smaller lumen diameter.

For complete angiographic evaluation of symptomatic post-CABG patients, both native coronary arteries and bypass grafts need to be assessed. Assessment of distal runoff segments yielded a sensitivity and specificity of $50 \%$ and $98 \%$, respectively, indicating that most of the lesions were correctly ruled out, although at the expense of stenosis underestimation. Consistent with prior similar reports, [9-13] evaluation of native distal runoffs in patients after CABG resulted in lower diagnostic accuracy compared to studies on native coronary segments in patients without previous CABG $[4,5]$. This discrepancy might be attributed to the advanced atherosclerosis with a high prevalence of severe calcifications and smaller caliber of distal runoffs in post-CABG patients. Interestingly and contrary to CTA-derived grafts assessment, the analysis of distal runoffs revealed false-negative lesions decreasing sensitivity. We hypothesize that underestimation of stenosis degree could be secondary to high calcium deposits with partial volume effect, and limited spatial resolution in smaller coronary branches.

There are some limitations that have to be taken into account when interpreting our data. First, the number of patients was low, and this was a single center experience. Second, as the prevalence of significant graft disease was high - secondary to the fact that individuals scheduled for ICA constituted our population - the diagnostic accuracy might be biased in asymptomatic patients after CABG. However, with excellent negative predictive values on the per-graft (100\%) and the per-anastomosis (100\%) basis, confirmed by the per-patient analysis, the noninvasive CTA might help to avoid an unnecessary number of cardiac catheterizations. This should be even more robust in a population with lower prevalence of significant graft disease. Third, the potential relation between calcium deposits or arrhythmia, and CTA false results was not assessed. Finally, the assessment of non-grafted native coronary arteries was not presented since it constitutes the subject of another manuscript.

\section{Conclusions}

In summary, dual-source CTA permits the noninvasive assessment of bypass graft patency and stenoses with high diagnostic accuracy. The high sensitivity and the excellent negative predictive value demonstrate that CTA can be used in clinical routine as a noninvasive test to rule out suspected graft dysfunction in symptomatic post-CABG patients.

\section{References}

1. Cameron AA, Davis KB, Rogers WJ. Recurrence of angina after coronary artery bypass surgery: predictors and prognosis (CASS registry). Coronary Artery Surgery Study. J Am Coll Cardiol 1995; 26: 895-899.

2. Lund C, Nes RB, Ugelstad TP, et al. Cerebral emboli during left heart catheterization may cause acute brain injury. Eur Heart J 2005; 26: 1269-1275.

3. Clark AL, Brennan AG, Robertson LJ, et al. Factors affecting patient radiation exposure during routine coronary angiography in a tertiary referral centre. Br J Radiol 2000; 73: 184-189.

4. Raff GL, Gallagher MJ, O'Neill WW, et al. Diagnostic accuracy of noninvasive coronary angiography using 64-slice spiral computed tomography. J Am Coll Cardiol 2005; 46: 552-557.

5. Leber AW, Knez A, von Ziegler F, et al. Quantification of obstructive and nonobstructive coronary lesions by 64-slice computed tomography: a comparative study with quantitative coronary angiography and intravascular ultrasound. J Am Coll Cardiol 2005; 46: $147-154$ 
6. Martuscelli E, Romagnoli A, D’Eliseo A, et al. Evaluation of venous and arterial conduit patency by 16-slice spiral computed tomography. Circulation 2004; 110: 3234-3238.

7. Burgsthaler C, Beck T, Kuettner A, et al. Non-invasive evaluation of coronary artery bypass grafts using 16-row multi-slice computed tomography with 188 ms temporal resolution. Int J Cardiol 2006; 106: 244-249.

8. Stein PD, Beemath A, Skaf E, et al. Usefulness of 4-, 8-, and 16slice computed tomography for detection of graft occlusion or patency after coronary artery bypass grafting. Am J Cardiol 2005; 96: 1669-1673.

9. Pache G, Saueressig U, Frydrychowicz A, et al. Initial experience with 64-slice cardiac CT: non-invasive visualization of coronary artery bypass grafts. Eur Heart J 2006; 27: 976-980.

10. Meyer TS, Martinoff S, Hadamitzky M, et al. Improved noninvasive assessment of coronary artery bypass grafts with 64-slice computed tomographic angiography in an unselected patient population. J Am Coll Cardiol 2007; 49: 946-950.

11. Malagutti P, Nieman K, Meijboom WB, et al. Use of 64-slice CT in symptomatic patients after coronary bypass surgery: evaluation of grafts and coronary arteries. Eur Heart J 2007; 28: 1879-1885.
12. Ropers D, Pohle FK, Kuettner A, et al. Diagnostic accuracy of noninvasive coronary angiography in patients after bypass surgery using 64-slice spiral computed tomography with 330-ms gantry rotation. Circulation 2006; 114: 2334-2341.

13. Nazeri I, Shahabi P, Tehrai M, et al. Assessment of patients after coronary artery bypass grafting using 64-slice computed tomography. Am J Cardiol 2009; 103: 667-673.

14. Flohr TG, McCollough $\mathrm{CH}$, Bruder $\mathrm{H}$, et al. First performance evaluation of a dual-source CT (DSCT) system. Eur Radiol 2006; 16: 256-268.

15. Achenbach S, Ropers D, Kuettner A, et al. Contrast-enhanced coronary artery visualization by dual-source computed tomography-initial experience. Eur J Radiol 2006; 57: 331-335.

16. Johnson TR, Nikolaou K, Wintersperger BJ, et al. Dual-source CT cardiac imaging: initial experience. Eur Radiol 2006; 16: 1409-1415.

17. Weustink AC, Nieman K, Pugliese F, et al. Diagnostic accuracy of computed tomography angiography in patients after bypass grafting: comparison with invasive coronary angiography. JACC Cardiovasc Imaging 2009; 2: 816-824. 